\title{
MEASURING THE SOIL COMPACTION ZONE AND PRESSURE OF DEFORMED SOIL ON UNDERGROUND OBJECTS WITH AN ASYMMETRIC CYLINDRICAL TIP
}

\author{
Suponyev V. M. ${ }^{1}$, Fidrovska N. M. ${ }^{1}$, Balesnyi S. P. ${ }^{1}$, Ragulin V. M. ${ }^{1}$, Kravets S. V. \\ ${ }^{1}$ Kharkiv National Automobile and Highway University \\ ${ }^{2}$ National University of Water and Environmental Engineering
}

\begin{abstract}
At trenchless laying of engineering communications in soil the method of static puncture has received wide application at formation of a well. Power plants that implement it have small dimensions, which make them more effective in laying distribution engineering networks in tight urban conditions. Problem. The main disadvantages of the method are the low accuracy of the trajectory and the significant stress in the soil after its compaction, which can lead to the destruction of adjacent underground objects. The first disadvantage is solved by controlling the trajectory of the soil-piercing working body. To solve the second question, it is necessary to know and take into account the specifics of the formation of communication cavities in the soil with an asymmetric tip, which is used for this purpose. Goal. The aim of the work is to establish the regularity of the process of soil puncture by the soil-piercing working body with an asymmetric tip in the form of a cylinder cut at an angle. Methodology. The approaches adopted in the work to solve this goal are based on the theories of deep soil cutting, scientific foundations of soil mechanics, their normative physical and mechanical properties and the law of conservation of soil mass before and after compaction. Results. The calculated dependences for determining the size of the destructive zone from the elastic-plastic deformation of the soil during its puncture by an asymmetric tip with a frontal surface in the form of a beveled cylinder and the pressure of the deformed soil on underground objects are obtained. It is established that the maximum size of the destruction zone and its pressure on underground objects will occur in solid sand. With a tip diameter of $0.3 \mathrm{~m}$, their values can reach $5 \mathrm{~m}$ and $0.245 \mathrm{MPa}$, respectively. Originality. The obtained regularities of soil puncture by a working body with an asymmetric tip in the form of a beveled cylinder made it possible to get an idea of the influence of its deformed state on adjacent communications depending on geometric parameters of the tip and physical and mechanical properties of soils. Practical value. The obtained results can be recommended in the design and determination of technological capabilities of installations for static soil puncture.
\end{abstract}

Key words: trenchless technologies, soil puncture, soil compaction, engineering communications, horizontal well, communication cavity.

\section{Introduction}

Among the existing technologies of developing horizontal wells for trenchless laying of utilities, the method of static soil puncture is the most common. Its main disadvantages are the low accuracy of the trajectory and the significant stress in the soil after its radial compaction with a conical tip, which may cause the destruction of adjacent underground communications and other objects. If the first disadvantage can be solved due to the controlled puncture of the soil, the second disadvantage must be taken into account considering the specifics of the asymmetric tip, which is used. Getting the idea of the level of density and pressure of deformed soil on underground objects with an asymmetric cylindrical tip will improve the quality of work and save from destruction the adjacent communications or other underground structures that occur in the way.

\section{Analysis of publications}

Horizontally directed well drilling and controlled drilling of the soil are currently the main directions for development of trenchless technologies of laying communications. The initial stage of development of communication cavities in the soil for both methods is formation of a leading horizontally directed well with a projectdefined trajectory of future networks running.

The process of advancing the working body of cylindrical shape and the resulting resistance forces which is determined by the parameters of the working body and the properties of the developed soil is described by the authors in [1-3].

From the system analysis of the world scientific periodical and technical literature, works 
$[4,5]$ can be distinguished, where the technologies of developing horizontally directed wells with the use of active working equipment on the ground - by impact and by drilling - are considered. However, they pay little attention to static puncture.

In works $[5,6]$ the systematic approach to choosing the method of work is considered with the detailed analysis of advantages and disadvantages of various methods of well development. Trenchless technologies of construction and repair of linear-long pipelines are dealt with in the studies resulted in works $[7,8]$. The research in [9] is devoted to choosing the method and planning of especially responsible works performed during trenchless laying of underground communications. But in the algorithm of selecting the technologies offered by authors, their destructive influence from the deformed soil on adjoining underground communications is not considered.

In [10] the possibilities of expansion of trenchless technologies to the necessary sizes and the methods of work are described.

The influence of soil on communications located near the trajectory along which the working body passes during a static puncture is described in studies [11].

The results of field tests and their comparison with the calculated values of axial forces during dynamic soil puncture are given in $[12,13]$. But none of the authors of these works pays enough attention to the static puncture of the soil by a working body with an asymmetrical tip.

We will particularly highlight the study of the possibility to implement trenchless technologies in hard rocks [14] or soils of categories 4-5.

Scientists have made extensive studies lately working on the problem of trenchless construction of underground communications with minimal energy consumption. Thus, in $[2,15]$ much attention is paid to soil puncture at short distances up to $25-30 \mathrm{~m}$. The study of the process of static soil puncture and its stresses around the working body during the well formation is reflected in [16]. However, the proposed empirical dependences are not widely used and are limited by the soil conditions of the experiments.

The zone of soil destruction around conicalcylindrical tips, piercing the soil, and cylindrical tips with an annular cross-section was determined in $[1,17,18]$. It was found that for conical-cylindrical tips that work on the principle of displacement of the soil in the side walls of the well the fracture zone is within $4 \ldots 6$ well di- ameters. For cylindrical tips with an annular cross-section, which work on the combined principle, when the soil is partially extruded by a pointed conical working edge on the outer contraction and partially penetrates into the pipe cavity, is within 2 diameters. In the latter case, the zone of destruction is determined experimentally for a specific type of soil with certain physical and mechanical properties, which also limits the use of the results. In addition, the problem of determining the pressure of the deformed soil on the adjacent underground objects was not considered by the authors.

For the first time, analytical dependences for determining the density and pressure of deformed soil on underground objects by working bodies with ring-shaped tips for pushing the soil were considered in [19]. For the asymmetric cylindrical tip, the case was not considered.

Thus, from the obtained analysis of solving the problem of determining the density and pressure of deformed soil on underground objects with an asymmetric cylindrical tip can be considered relevant both in science and practice terms.

\section{Purpose and Tasks}

The goal of the work is to determine the density and pressure of deformed soil on underground objects with an asymmetric cylindrical tip.

In accordance with this goal, the dependence should be determined to establish the scale of the change in soil density around the asymmetric cylindrical tip and the pressure of deformed soil on underground objects and adjacent utilities, taking into account physical and mechanical properties of soils and geometric parameters of the soil-piercing tool tip.

\section{Measuring the zone of soil density when it is punctured by an asymmetric cylindrical tip}

The object of this study is a soil-piercing working body for static controlled formation of a well in the soil using a soil-piercing working body with an asymmetric tip. The lack of analytical calculations to measure the zone of soil density change relative to its initial natural state around such a tip does not allow making a full analysis of the puncture process or determining the impact of deformed soil on adjacent communications and other underground objects near the future network.

A schematic representation of an asymmetrical cylindrical tip with a beveled front surface is shown in Fig. 1. 


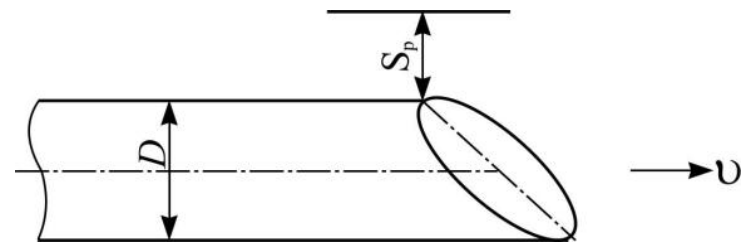

Fig. 1. Scheme of an asymmetric cylindrical tip

Resistance to the advancement of the working body with an asymmetric tip in the form of a cylinder with a frontal angled surface was considered in [19]. Rational dimensions of the angle of frontal surface inclination relative to the axis of the cylinder were also determined for different types of punctured soils, respectively: hard sand, semi-hard loam, tough clay. However, the size of the soil density zone when it was punctured with such a tip and its destructive effect on the adjacent utilities and other underground objects were not determined.

The diameter of the asymmetric cylindrical tip is determined by the diameter of the cases or protective pipes of running communications, which must be freely drawn into the created cavity. According to the calculations obtained in [3], the size of the most effective diameter is limited to $300 \ldots 350 \mathrm{~mm}$.

In the conditions of dense construction in cities and a large number of underground communication engineering networks, control of movement of a working body with an asymmetric cylindrical tip allows to increase efficiency of trenchless laying of new underground communications with the use of small-sized static action installations operating on the principle of crushing by power hydraulic cylinders of a working body with a possibility of controlling its trajectory of movement in the soil.

One of the problem areas that need to be studied is the impact of the soil compacted from the advancement of the working body on the adjacent communications and other underground structures arising from the action of the transverse component of resistance from the beveled frontal surface of the tip on the soil during deviation of the working body from axial movement. Studying the impact of soil deformation zone on them will provide an opportunity to improve the quality of horizontal directed wells, eliminate the risks of damage or destruction of communications and generally improve the efficiency of work.

Based on the law of conservation of soil mass before and after destruction in accordance with (Fig. 1) we have:

$$
\left(\frac{\pi D^{2}}{4}+D S_{p}\right) \rho_{n s}=D \int_{0}^{S_{p}} \rho_{x} d x,
$$

where $S_{\mathrm{p}}$ is the soil destruction zone;

$\rho_{x}$ is variable soil density along the length of the destruction zone;

$\rho_{n s}$ is the soil density in its natural state.

In this expression $\frac{\pi D^{2}}{4}+D S_{p}$ is the crosssectional area of the soil before destruction.

In the first approximation, the regularity of the change in density of the soil mass $\rho_{x}$ can be assumed to be linear depending on the distance to the side wall [17] (Fig. 2):

$$
\rho_{x}=\rho_{\max }-\left(\rho_{\max }-\rho_{n s}\right) \frac{x}{S_{p}},
$$

where $\rho_{\max }$ is the maximum density of the soil in the side wall of the hole, which acts when $x=0$ and is in the opposite direction from the bevel of the front surface of the cylinder.

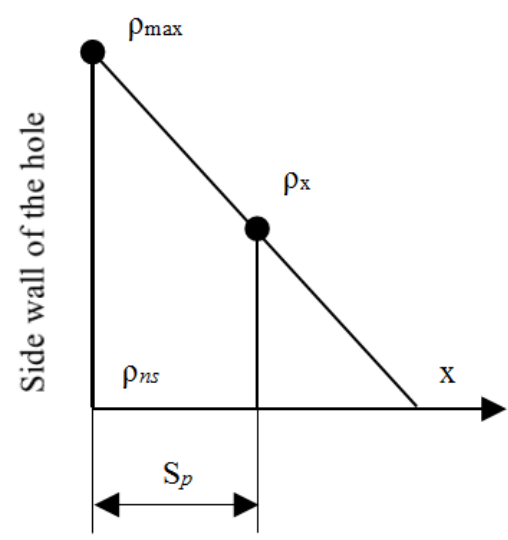

Fig. 2. Regularity of changes in soil density in the zone of destruction

Taking into account (2), equation (1) will be rewritten as:

$$
\begin{gathered}
\left(\frac{\pi D^{2}}{4}+D S_{p}\right) \rho_{n s}= \\
=D \int_{0}^{S_{p}}\left[\rho_{\max }-\left(\rho_{\max }-\rho_{n s}\right) \frac{x}{S_{p}}\right] d x= \\
=D\left[\rho_{\max } S_{p}-\left(\rho_{\max }-\rho_{n s}\right) \frac{S_{p}}{2}\right]= \\
=\frac{\rho_{\max }+\rho_{n s}}{2} D S_{p}=\rho_{a v} D S_{p}
\end{gathered}
$$


According to the data in sources [1, 17], the value of the average soil density $\rho_{a v}$ depending on its initial natural state is:

$$
\rho_{a v}=\frac{\lambda^{2} \rho_{n s}}{\lambda^{2}-1},
$$

where $\lambda=4,0 \ldots 6,0$ is coefficient depending on the soil type and depth of puncture [6];

$\rho_{n s}$ is the natural density of soil before destruction.

Approximately the value of the average soil density can be taken as:

$$
\rho_{a v}=(1.05 \ldots 1.1) \rho_{n s} .
$$

If we take into account that for solid sand $\rho_{a v}=2.05 \mathrm{t} / \mathrm{m}^{3} ;$ for semi-hard loam $\rho_{a v}=2.10 \mathrm{t} / \mathrm{m}^{3}$; for tough clay $-\rho_{a v}=2,00 \mathrm{t} / \mathrm{m}^{3}$, then, based on equation (3), the size of the zone of soil destruction can be determined by the following expression:

$$
S_{p}=(7.85 \ldots 15.7) D,
$$

where $\mathrm{S}_{p}=7.85 D$ is for the tip with diameter $D=0.13 \mathrm{~m}$;

$\mathrm{S}_{p}=15.7 \mathrm{D}$ is for the tip with diameter $D=0.325 \mathrm{~m}$.

Determining the deformed soil pressure on underground objects during its puncture with an asymmetric cylindrical tip

The pattern of changes in soil pressure on underground communications, which fall into the area of elastic-plastic deformations of the soil, can be represented by dependence [17]:

$$
\begin{gathered}
q_{x}=\frac{1+\omega}{C_{c}} \rho_{s p}\left(\frac{1}{\rho_{n s}}-\frac{1}{\rho_{x}}\right)= \\
=\frac{(1+\omega) \rho_{s p}}{C_{c} \rho_{n s}}\left[1-\frac{\rho_{n s}}{\rho_{\max }-\left(\rho_{\max }-\rho_{n s}\right) \frac{x}{S_{p}}}\right],
\end{gathered}
$$

where $\omega$ is the soil moisture;

$\rho_{s p}$ is density of the solid phase of the soil, i.e., when there are no pores;

$C_{c}$ is soil compression ratio.

If we assume that $\rho_{\max }=1.1 \rho_{n s}$ for the tip with the cylinder diameter $\mathrm{D}=0.13 \mathrm{~m}$ and $\rho_{\max }=1.2 \rho_{n s}$ for the tip with a diameter $\mathrm{D}=0.325 \mathrm{~m}$, the dependence of the pressure distribution will take the form:

$$
q_{x}=E_{s}\left[1-\frac{1}{(1.1 \ldots 1.2)-(0.1 \ldots 0.2) \frac{x}{S_{p}}}\right] \text {, }
$$

where $E_{s}=\frac{(1+\omega) \rho_{s p}}{C_{c} \rho_{n s}}$ is the compression module of soil deformation.

If $x=0$, then $\mathrm{q}_{\max }=(0.126 \ldots 0.23) E_{s} . \mathrm{MPa}-$ for solid sand; $\mathrm{q}_{\max }=(0.081 \ldots 0.148) E_{s}, \mathrm{MPa}-$ for semi-solid loam; for tough clay it is $\mathrm{q}_{\max }=(0.057 \ldots 0.104) E_{s} \mathrm{MPa}$.

At a distance from the side wall $x=S_{p}$ the soil pressure will be minimal, $\mathrm{q}_{\min }=0$.

To calculate the modulus of elasticity of soil deformation the following can be taken: for sandy loam $-E_{s}=1.36 \mathrm{MPa}$; for loam $E_{\text {гр }}=0.892 \mathrm{MPa}$; for clay $-E_{s}=0.63 \mathrm{MPa}$.

The changes in soil pressure on underground communications, which fall into the zone of elastic-plastic deformations at the average values of the obtained initial data are shown in graphical form in Fig. 3 for two cases of tip diameter $\mathrm{D}=0.13 \mathrm{~m}$ and $\mathrm{D}=0.325 \mathrm{~m}$.

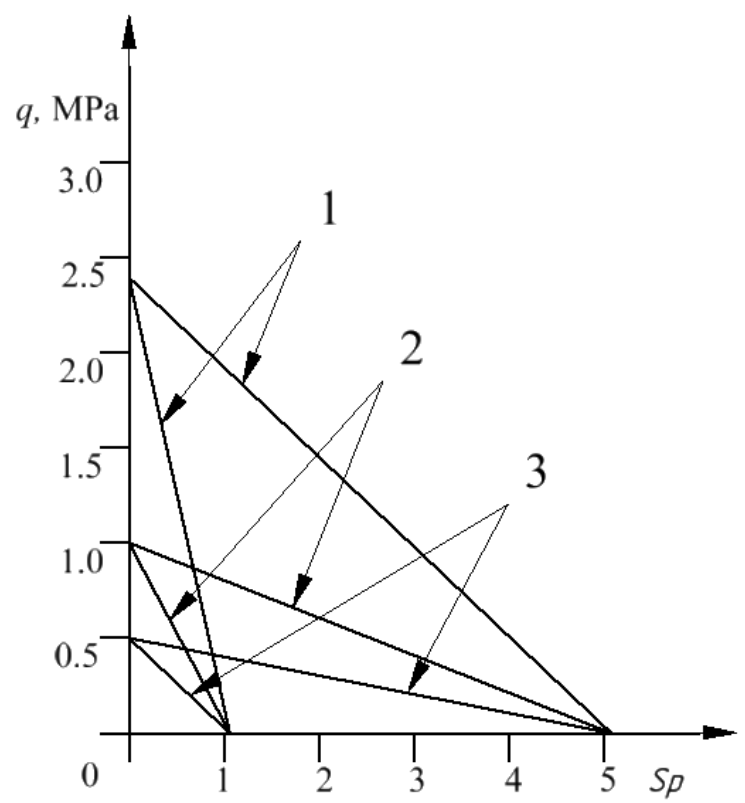

Fig. 3. Dependence of the change in soil density in the zone of destruction for diameters of the tip $\mathrm{D}=0.13 \mathrm{~m}$ and $\mathrm{D}=0.325 \mathrm{~m}$ in its different types: 1 - in solid sand; 2 - in semihard loam; 3 - in tough clay 
The graph in Fig. 3 shows that the size of the fracture zone in all types of soils is approximately the same and significantly depends on the size of the diameter of the tip (or well). With a maximum well diameter $\mathrm{D}=0.325 \mathrm{~m}$, which is recommended when using the technology of static soil puncture, the size of the zone of elasticplastic deformation, or possible destructive action on adjacent underground objects can reach more than $5 \mathrm{~m}$.

The average maximum pressure in this case will be in close proximity to the tip and is $0.245 \mathrm{MPa}$ in the formation of a well in hard sand, $0.103 \mathrm{MPa}$ - in semi-hard loam and $0.050 \mathrm{MPa}-$ in tough clay.

The obtained pressure values allow to calculate the strength of the communications adjacent to the route or other underground objects and to establish the distance to them. This is especially important when developing soil cavities in dense urban conditions.

\section{Conclusion}

From a comprehensive analysis of the technical literature, it was determined that the expansion of the most effective and most common static method of soil puncture in trenchless utilities is possible by increasing the puncture distance through controlling the trajectory of the working body. Its tip should have an asymmetrical shape, one of them is a cylinder with a beveled front surface.

The research established the dimensions of the zones of lateral soil compaction in the process of soil puncture with an asymmetric cylindrical tip with a frontal surface in the form of an inclined plane, which is determined by the initial natural state of the soil and the diameter of the formed well.

It is determined that at the maximum diameter of the well $\mathrm{D}=0.325 \mathrm{~m}$, which is recommended when using the technology of static soil puncture, the size of the zone of elastic-plastic deformation or possible destructive action on adjacent underground objects can reach more than $5 \mathrm{~m}$.

The regularity of soil density distribution on the opposite side from the bevel of the frontal surface is established and the maximum pressure that can act on the adjacent underground objects is specified, which is determined by its type and compression modulus of soil deformation.

It was estimated that the average maximum pressure of deformed soil in the immediate vicinity of the tip is $0.245 \mathrm{MPa}$ in the formation of wells in hard sand, $0.103 \mathrm{MPa}$ - in semi-hard loam and $0.050 \mathrm{MPa}-$ in tough clay.
The obtained ideas of the regularities of formation of soil consolidation zone and the zone of pressure from its deformation on underground objects from the action of an asymmetric cylindrical tip on it can be recommended for consideration at designing and executing works at trenchless laying of underground communication networks.

\section{Література}

1. Кравець С. В., Кованько В. В., Лукянчук О. П. Наукові основи створення землерийноярусних машин і підземнорухомих пристроїв. Монографія. Рівне: НУВГП, 2015. 322 с.

2. Кравець С., Посмітюха О., Супонєв В. Аналітичний спосіб визначення опору занурення конусного наконечника в грунт. СММ ПДАБА. Вып. 103. 2017. С. 91-98.

3. Кравець С., Посмітюха О., Супонєв В. Визначення еквівалентного i оптимального діаметрів конічного наконечника 3 виступами для проколювання грунту. НПТ ДНУЗТ. Вип. 70. 2017. C. 89-98.

4. Erez N. Allouche, Samuel T. Ariaratnam, StateOf-The-Art-Review Of No-Dig Technologies for New Installations. Pipeline Division Specialty Conference: $\quad$ April 26. 2012. https://doi.org/10.1061/40641(2002)55.

5. Pridmore A., Geisbush J. Developing a Successful Specification for Horizontal Directional Drilling. Pipelines 2017. Pipelines Planning and Design Book set. 2017. P. 553-563. https://doi.org/10.1061/9780784480878.

6. Hastak M., Gokhale S., Decision Tool for Selecting the Most Appropriate Technology for Underground Conduit Construction. Geological Engineering: Proceedings of the 1st International Conference. New York, 2009. DOI: 10.1115/1.802922.paper30.

7. Zhao Jun Ling Bian. Trenchless technology underground pipes. Machinery Industry Press, 2014. P. 187.

8. Jian Xin. Application of Trenchless Pipeline Rehabilitation Technology. International Conference on Pipelines and Trenchless Technology. 2014. https://doi.org/10.1061/9780784413821.051.

9. Hastak Makarand, Gokhale Sanjiv. Decision Tool for Selecting the Most Appropriate Technology for Underground Conduit Construction. Geological Engineering: Proceedings of the 1st International Conference, Baosong Ma, ASME. doi: 10.1115/1.802922.paper30.

10. Sterling Raymond L. International Technology Transfer in Tunneling and Trenchless Technology. Geological Engineering: Proceedings of the 1st International Conference. Baosong Ma, ASME, 2009. doi: 10.1115/1.802922.paper6.

11. Nilo Tsung, Mingming Zheng, Mohammad Najafi, Saleh Mehraban. A Comparative Study of Soil Pressure and Deformation of Pipes Installed 
by the Open-Cut Method and Trenchless Technology. Pipelines 2016: Out of Sight, Out of Mind, Not Out of Risk. 2016. https://doi.org/10.1061/9780784479957.132.

12. Najafi Mohammad, Gunnink Brett, Davis George. Details of Field Testing of Major Trenchless Technology Methods for Road Crossings. Geological Engineering: Proceedings of the 1st International Conference, Baosong Ma, ASME, 2009. doi: 10.1115/1.802922.paper4.

13. Chehab A. G., Moor I. D. One-demensional calculation for axial pullback for axial pullback distributions in pipes during directional drilling installations. Ottava Geo, 2007. P. 1140-1154.

14. Guojun Wen, Xiaoming Wu, Han Chen. Trenchless Pipe-Paving in Complex Hard Stratum by Directional Drilling Technology. Geological Engineering: Proceedings of the 1st International Baosong Ma, ASME. New York, 2009. doi: 10.1115/1.802922.paper26.

15. Балесный С. Особенности процессов статического прокола грунта. Вісник ХНАДУ. 2017. Вып. 76. С. 138-141.

16. Хачатурян С., Олексин В. Исследование процесса изменения состояния грунта вокруг горизонтальной скважины после её формирования методом статического прокола грунта. Вісник ХНАДУ. Вып. 73. 2016. С. 196-202.

17. Ешуткин Д. Н., Смирнов Ю.М., Цой В.И., Исаев В.Л. Высокопроизводительные гидропневматические ударные машины для прокладки инженерных коммуникаций. Москва: Стройиздат, 1990. $171 \mathrm{c.}$

18. Полтавцев И. С., Орлов В.Б., Ляхович И.Ф. Специальные землеройные машины и механизмы для городского строительства. Киев: Будівельник, 1973. 156 с.

19. Супонєв В.М. Визначення величини зони деформування грунту конусно-циліндричним наконечником і тиску на бічній поверхні. Вестник ХНАДУ: сб. науч. тр. 2018. Вып. 83. C. $22-28$.

\section{References}

1. Kravets S., Kovalenko V., Lukyanchuk O. (2015). Naukovi osnovy stvorennia zemleryinoyarusnykh mashyn i pidzemnorukhomykh prystroiv. [Scientific basis for the construction of earth-tiered machines and underground machine tools]. Monograph. Rivne: NUVGP. [in Ukrainian].

2. Kravets, S., Posmituha, O., Suponnev, V. (2017). Analitychnyi sposib vyznachennia oporu zanurennia konusnoho nakonechnyka $\mathrm{v}$ grun. [An analytical method for determining the resistance of immersion of a conical tip into the soil]. SMM PDABA, 103, 91-98. [in Ukrainian].

3. Kravets S., Posmituha O., Suponnev V. (2017). Vyznachennia ekvivalentnoho i optymalnoho diametriv konichnoho nakonechnyka $\mathrm{Z}$ vystupamy dlia prokoliuvannia gruntu. [Determi- nation of equivalent and optimal diameters of a conical tip with projections for puncturing the soil]. NPT DNUZT, 70, 89-98. [in Ukrainian].

4. Erez N., Allouche Samuel A. (2012). State-OfThe-Art-Review Of No-Dig Technologies for New Installations. American Society of Civil Engineers, 8. https://doi.org/10.1061/40641(2002)55.

5. Pridmore A., Geisbush J. (2017). Developing a Successful Specification for Horizontal Directional Drilling. Pipelines 2017. Pipelines Planning and Design Book set, 553-563.

6. Hastak M., Gokhale S. (2009). Decision Tool for Selecting the Most Appropriate Technology for Underground Conduit Construction. Geological Engineering: Proceedings of the 1st International Conference. New York, 18.

7. Zhao Jun Ling Bian. (2014). Trenchless technology underground pipes. Machinery Industry Press, 187.

8. Jian Xin. (2014). Application of Trenchless Pipeline Rehabilitation Technology. International Conference on Pipelines and Trenchless Technology. https://doi.org/10.1061/9780784413821.051.

9. Hastak Makarand, Gokhale Sanjiv. (2009). Decision Tool for Selecting the Most Appropriate Technology for Underground Conduit Construction. Geological Engineering: Proceedings of the 1st International Conference, Baosong $\mathrm{Ma}$, ASME. New York, 18.

10. Sterling Raymond L. (2009). International Technology Transfer in Tunneling and Trenchless Technology. Geological Engineering: Proceedings of the 1st International Conference. Baosong Ma, ASME. New York, 8.

11. Nilo Tsung, Mingming Zheng, Mohammad Najafi, Saleh Mehraban. (2016). A Comparative Study of Soil Pressure and Deformation of Pipes Installed by the Open-Cut Method and Trenchless Technology. Pipelines 2016: Out of Sight, Out of Mind, Not Out of Risk.

12. Najafi M., Brett G., Davis G. (2009). Details of Field Testing of Major Trenchless Technology Methods for Road Crossings. Geological Engineering: Proceedings of the 1st International Conference, Baosong Ma, ASME. New York, 9.

13. Chehab A. G., Moor I. D. (2007). Onedemensional calculation for axial pullback for axial pullback distributions in pipes during directional drilling installations. OttavaGeo, 11401154.

14. Guojun Wen, Xiaoming Wu, Han Chen. (2009). Trenchless Pipe-Paving in Complex Hard Stratum by Directional Drilling Technology. Geological Engineering: Proceedings of the 1st International Conference (ICGE 2007), Baosong Ma, ASME. New York, 8.

15. Balesny S. (2017). Osobennosti processov staticheskogo prokola grunta [Features of the process of static puncture of the soil]. VKHADU, 76, 138-141. [in Russian]. 
16. Khachaturian S., Oleksin V. (2016). Issledovanie processa izmeneniya sostoyaniya grunta vokrug gorizontal'noj skvazhiny posle eyo formirovaniya metodom staticheskogo prokola grunta [The study of the process of changing the state of the soil around a horizontal well after its formation by the method of static puncture of the soil]. VKHADU, 73, 196-202. [in Russian].

17. Sushutkin D. N., Smirnov Yu. M., Tsoi V. I., Isayev V. L. (1990). Vysokoproizvoditel'nye gidropnevmaticheskie udarnye mashiny dlya prokladki inzhenernyh kommunikacij [Highperformance hydropneumatic shock machines for laying engineering communications]. Moscow: Stroyizdat, 171. [in Russian].

18.Poltavcev I. S., Orlov V.B., Полтавцев И. С., Lzhovich I. F. (1973). Special'nye zemlerojnye mashiny i mekha-nizmy dlya gorodskogo stroitel'stva [Special digging machines and mechanisms for urban construction]. Kiev: Dudivelnik. [in Russian].

19. Suponev V. M. (2018) Vyznachennia velychyny zony deformuvannia gruntu konusnotsylindrychnym nakonechnykom i tysku na bichnii poverkhni [Viznachennya velichini zoni deformuvannya rruntu konusno-cilindrichnim nakonechnikom i tisku na bichnij poverhni]. Vestnik HNADU: sb. nauch. tr. 83. 22-28. [in Ukrainian].

Vladimir Suponyev ${ }^{1}$, DSci (Engineering), Assoc. Prof. Department of build and travelling machines, vsuponev@ukr.net, tel.: +38050-30-199-58, ORCID: http://orcid.org/0000-0001-7404-6691

Nataliia Fidrovska ${ }^{1}$, DSci (Engineering), Professor Department of build and travelling machines, nfidrovskaya@ukr.net, tel.: +38099-790-55-34, ORCID: http://orcid.org/0000-0002-5248-273X

Sergii Balesnyi ${ }^{1}$, Director Transport Infrastructure Design Institute LLC, sp.balesnyi@gmail.com, tel.: +38-050-343-80-34, ORCID:

https://orcid.org/0000-0002-9216-3944

Vitaliy Ragulin ${ }^{1} \mathrm{PhD}$, Assoc. Prof. Department of build and travelling machines, ragulinrvn@ukr.net, tel.: +38-050-545-80-70,

ORCID: https://orcid.org/0000-0003-2083-4937

Svyatoslav Kravets ${ }^{2}$, DSci (Engineering), Professor Department of building, road, melioration, agricultural machinery and equipment,

tel. 097-28-915-89, s.v.kravets@ nuwm.edu.ua, ORCID: http://orcid.org/0000-0003-4063-1942

${ }^{1}$ Kharkiv National Automobile and Highway University Yaroslava Mudrogo str., 25, Kharkiv, Ukraine, 61002

${ }^{2}$ National University of Water and Environmental

Engineering, Soborna str., 11, Rivne, Ukraine, 33028

Визначення величини зони ущільнення грунту та тиску деформованого грунту на підземні об'скти асиметричним циліндричним наконечником
Анотація. У процесі безтраншейного прокладанні інженерних комунікаџій у трунті широке застосування у формуванні свердловини отримав метод статичний проколу. Силові установки, які його реалізують, мають малі габарити, щзо робить їх ефективнішими в прокладанні розподільних інженерних мереж у стислих міських умовах. Проблема. Головними недоліками методу є низька точність траєкторії та значне напруження в трунті після його ущільнення, яке може спричинити руйнування прилеглих підземних об'єктів. Перший недолік вирішується керуванням траєкторії руху трунтопроколюючого робочого органу. Для вирішення другого питання треба знати та враховувати специфіку формування комунікаційних порожнин у трунті асиметричним наконечником, який для цьвого використовується. Мета. Метою роботи є встановлення закономірності процесу проколу трунту трунтопроколюючим робочим органом з асиметричним наконечником у вигляді зрізаної під кутом ичиліндра. Методологія. Прийняті в роботі підходи до вирішення поставленої мети базуються на уявленнях теорій глибокого різання трунту, наукових основ механіки трунтів, їхніх нормативних фізико-механічних властивостей та закону збереження маси трунту до його ущільнення та після. Результати. Отримані розрахункові залежності для визначення розміру руйнівної зони від пружно-пластичної деформації трунту в процесі його проколювання асиметричним наконечником із лобовою поверхнею у вигляді скошеного ичиліндра та тиску деформованого трунту на підземні об'єкти. Установлено, щзо максимальний розмір зони руйнування та його тиску на підземні об'єкти будуть виникати в твердому супіску. Якщо діаметр наконечника 0,3 м. їхні величини можуть досягати 5 м та 0,245 МПа відповідно. Оригінальність. Отримані закономірності проколу трунту робочим органом з асиметричним наконечником у вигляді скошеного ичиліндра надали змогу отримати уявлення про вплив його деформованого стану на прилеглі комунікації залежно від геометричних параметрів наконечника та фізико-механічних властивостей трунтів, у яких він відбувається. Практичне значення. Отримані результати можуть бути рекомендовані в проєктуванні та визначенні технологічних можливостей установок для статичного проколу трунту.

Ключові слова: безтраншейні технологї, прокол трунту, ущільнення трунту, інженерні комунікаиіiі, горизонтальна свердловина, комунікаційна порожнина.

Супонев Володимир Миколайович ${ }^{1}$, д.т.н., доцент кафедри будівельних і дорожніх машин iм. A.M. Холодова, v-suponev@ukr.net, тел.: +38050-30-199-58,

ORCID: http://orcid.org/0000-0001-7404-6691

Фідровська Наталя Миколаївна ${ }^{1}$, д.т.н., професор кафедри будівельних і дорожніх машин 
iм. А.M. Холодова, nfidrovskaya@ukr.net, тел.: +38099-790-55-34,

ORCID: http://orcid.org/0000-0002-5248-273X

Балесний Сергій Петрович ${ }^{1}$, директор ТОВ «Інститу проектування інфраструктури транспорту», sp.balesnyi@gmail.com,

тел.: +38-050-343-80-34,

ORCID: https://orcid.org/0000-0002-9216-3944

Рагулін Віталій Миколайович ${ }^{1}$, к.т.н., доцент кафедри будівельних і дорожніх машин

ім. А.М. Холодова, ragulinrvn@ukr.net, тел.: +38-050-545-80-70,

ORCID: https://orcid.org/0000-0003-2083-4937
Кравець Святослав Володимирович ${ }^{2}$, д.т.н., професор кафедри будівельних, дорожніх, меліоративних, сільськогосподарських машин i обладнання, тел. 097-28-915-89,

s.v.kravets@ nuwm.edu.ua,

ORCID: http://orcid.org/0000-0003-4063-1942

${ }^{1}$ Харківський національний автомобільнодорожній університет, вул. Ярослава Мудрого, 25, м. Харків, Україна, 61002

${ }^{2}$ Національний університет водного господарства та природокористування вул. Соборна, 11, м. Рівне, Україна, 33028. 